The University of Maine

\title{
DigitalCommons@UMaine
}

Earth Science Faculty Scholarship

Earth Sciences

6-27-2006

\section{The 1452 or 1453 A.D. Kuwae Eruption Signal Derived from Multiple Ice Core Records: Greatest Volcanic Sulfate Event of the Past 700 Years}

\author{
Chaochao Gao
}

Alan Robock

Stephen Self

Jeffrey B. Witter

J.P. Steffenson

See next page for additional authors

Follow this and additional works at: https://digitalcommons.library.umaine.edu/ers_facpub

Part of the Earth Sciences Commons

\section{Repository Citation}

Gao, Chaochao; Robock, Alan; Self, Stephen; Witter, Jeffrey B.; Steffenson, J. P.; Clausen, Henrik Brink; Siggard-Andersen, MarieLouise; Johnson, Sigfus; Mayewski, Paul Andrew; and Ammann, Caspar, "The 1452 or 1453 A.D. Kuwae Eruption Signal Derived from Multiple Ice Core Records: Greatest Volcanic Sulfate Event of the Past 700 Years" (2006). Earth Science Faculty Scholarship. 98. https://digitalcommons.library.umaine.edu/ers_facpub/98

This Article is brought to you for free and open access by DigitalCommons@UMaine. It has been accepted for inclusion in Earth Science Faculty Scholarship by an authorized administrator of DigitalCommons@UMaine. For more information, please contact um.library.technical.services@maine.edu. 


\section{Authors}

Chaochao Gao, Alan Robock, Stephen Self, Jeffrey B. Witter, J. P. Steffenson, Henrik Brink Clausen, MarieLouise Siggard-Andersen, Sigfus Johnson, Paul Andrew Mayewski, and Caspar Ammann 


\title{
The 1452 or 1453 A.D. Kuwae eruption signal derived from multiple ice core records: Greatest volcanic sulfate event of the past 700 years
}

\author{
Chaochao Gao, ${ }^{1}$ Alan Robock, ${ }^{1}$ Stephen Self, ${ }^{2}$ Jeffrey B. Witter, ${ }^{3}$ J. P. Steffenson, ${ }^{4}$ \\ Henrik Brink Clausen, ${ }^{4}$ Marie-Louise Siggaard-Andersen, ${ }^{4}$ Sigfus Johnsen, ${ }^{4}$ \\ Paul A. Mayewski, ${ }^{5}$ and Caspar Ammann ${ }^{6}$ \\ Received 26 September 2005; revised 22 January 2006; accepted 1 March 2006; published 27 June 2006.
}

[1] We combined 33 ice core records, 13 from the Northern Hemisphere and 20 from the Southern Hemisphere, to determine the timing and magnitude of the great Kuwae eruption in the mid-15th century. We extracted volcanic deposition signals by applying a highpass loess filter to the time series and examining peaks that exceed twice the 31 year running median absolute deviation. By accounting for the dating uncertainties associated with each record, these ice core records together reveal a large volcanogenic acid deposition event during 1453-1457 A.D. The results suggest only one major stratospheric injection from the Kuwae eruption and confirm previous findings that the Kuwae eruption took place in late 1452 or early 1453 , which may serve as a reference to evaluate and improve the dating of ice core records. The average total sulfate deposition from the Kuwae eruption was $93 \mathrm{~kg} \mathrm{SO} / \mathrm{km}^{2}$ in Antarctica and $25 \mathrm{~kg} \mathrm{SO} / \mathrm{km}^{2}$ in Greenland. The deposition in Greenland was probably underestimated since it was the average value of only two northern Greenland sites with very low accumulation rates. After taking the spatial variation into consideration, the average Kuwae deposition in Greenland was estimated to be $45 \mathrm{~kg} \mathrm{SO} / \mathrm{km}^{2}$. By applying the same technique to the other major eruptions of the past 700 years our result suggests that the Kuwae eruption was the largest stratospheric sulfate event of that period, probably surpassing the total sulfate deposition of the Tambora eruption of 1815, which produced $59 \mathrm{~kg} \mathrm{SO} / \mathrm{km}^{2}$ in Antarctica and $50 \mathrm{~kg} \mathrm{SO} / \mathrm{km}^{2}$ in Greenland.

Citation: Gao, C., A. Robock, S. Self, J. B. Witter, J. P. Steffenson, H. B. Clausen, M.-L. Siggaard-Andersen, S. Johnsen, P. A. Mayewski, and C. Ammann (2006), The 1452 or 1453 A.D. Kuwae eruption signal derived from multiple ice core records: Greatest volcanic sulfate event of the past 700 years, J. Geophys. Res., 111, D12107, doi:10.1029/2005JD006710.

\section{Introduction}

[2] The Kuwae volcano in Vanuatu $\left(16.83^{\circ} \mathrm{S}, 168.54^{\circ} \mathrm{E}\right)$ erupted in the middle of the 15th century A.D. [Pang, 1993; Briffa et al., 1998], expelling $32-39 \mathrm{~km}^{3}$ of dense rock equivalent [Monzier et al., 1994]. This volume of expelled matter is more than six times larger that of the 1991 Pinatubo eruption and left "unmistakable marks in world climate records" [Pang, 1993]. While records of unusual weather and atmospheric optical phenomena and severe damage on agriculture [Pang, 1993], as well as the

\footnotetext{
${ }^{1}$ Department of Environmental Sciences, Rutgers-State University of New Jersey, New Brunswick, New Jersey, USA.

${ }^{2}$ Department of Earth Sciences, Open University, Milton Keynes, UK.

${ }^{3}$ Hawaii Institute of Geophysics and Planetology, University of Hawaii at Manoa, Honolulu, Hawaii, USA.

${ }^{4}$ Niels Bohr Institute, University of Copenhagen, Copenhagen, Denmark.

${ }^{5}$ Climate Change Institute, University of Maine, Orono, Maine, USA.

${ }^{6}$ National Center for Atmospheric Research, Boulder, Colorado, USA.

Copyright 2006 by the American Geophysical Union. 0148-0227/06/2005JD006710
}

anomalously low tree ring densities [Briffa et al., 1998], point to the year 1452 as the time of the eruption, dating of the Kuwae signal derived from individual ice core record ranges from 1450 to 1464 . For example, ColeDai et al. [1997] found an acid "spike" that lasted for four years from 1454 to 1457 in the Siple Station ice core. Palmer et al. [2002] reported deposition of a large volcanic eruption during 1459-1461 in the Law Dome record, which was also found to be the largest volcanic signal in the last seven centuries in this record. Castellano et al. [2005] assigned the Kuwae signal to the year 1460 in their EPICA Dome C core. Another Antarctic ice core, PS1 [Delmas et al., 1992], displays a prominent acid peak which they determined to be about 1450. Similarly, in the Northern Hemisphere (NH), Zielinski et al. [1994] and Zielinski [1995] found a large volcanic signal at 1460 1461 in the GISP2 record. Fisher and Koerner [1994] discovered a volcanic deposition in 1455 in the A84 ice core. Bigler et al. [2002] found a large peak lasting several years in the early $1450 \mathrm{~s}$ in the NGT-B20 ice core. In several of these cores Kuwae is a major if not a dominant 
Table 1. Ice Core Time Series Used in the Study ${ }^{\mathrm{a}}$

\begin{tabular}{|c|c|c|c|c|c|c|c|}
\hline Name & Location & Period & Resolution & $\begin{array}{c}\text { Annual } \\
\text { Accumulation } \\
\text { Rate, mwe/yr }\end{array}$ & Measure Type & Units & Reference \\
\hline $\mathrm{A} 84^{\mathrm{b}}$ & $80.7^{\circ} \mathrm{N}, 73.1^{\circ} \mathrm{W}$ & $1223-1961$ & $1 / \mathrm{yr}$ & 0.098 & ECM & $\mu \mathrm{A}$ & Fisher et al. [1995] \\
\hline $\mathrm{A} 77^{\mathrm{b}}$ & $80.7^{\circ} \mathrm{N}, 73.1^{\circ} \mathrm{W}$ & $453-1853$ & $1 / \mathrm{yr}$ & 0.175 & ECM & $\mu \mathrm{A}$ & Fisher et al. [1995] \\
\hline NGT_B20 & $79^{\circ} \mathrm{N}, 36.5^{\circ} \mathrm{W}$ & $830-1993$ & $12 / \mathrm{yr}$ & 0.098 & CFA & ng/g (ppb) & Bigler et al. [2002] \\
\hline NorthGRIP1.ECM & $75.1^{\circ} \mathrm{N}, 42.3^{\circ} \mathrm{W}$ & $190-1969$ & $2 / \mathrm{yr}$ & 0.152 & ECM & & this paper \\
\hline NorthGRIP1.SO 4 & $75.1^{\circ} \mathrm{N}, 42.3^{\circ} \mathrm{W}$ & $190-1969$ & $1 / \mathrm{yr}$ & 0.152 & total $\mathrm{SO}_{4}$ & $\mu \mathrm{eq} / \mathrm{kg}$ & this paper \\
\hline $\mathrm{GISP}^{\mathrm{b}}$ & $72.6^{\circ} \mathrm{N}, 38.5^{\circ} \mathrm{W}$ & $1-1984$ & $0.5 / \mathrm{yr}$ & 0.420 & $\mathrm{NSS} \mathrm{SO}_{4}$ & $\mathrm{ppb}$ & Zielinski [1995] \\
\hline Dye3 deep & $72.6^{\circ} \mathrm{N}, 37.6^{\circ} \mathrm{W}$ & $1-1768$ & $4 / \mathrm{yr}$ & 0.500 & ECM & & this paper \\
\hline Greenland Site T & $72.6^{\circ} \mathrm{N}, 38.5 \mathrm{~W}$ & $1731-1989$ & $1 / \mathrm{yr}$ & 0.224 & EXS & $\mathrm{kg} / \mathrm{km}^{2}$ & Mosley-Thompson et al. [1993] \\
\hline GRIP main & $71.3^{\circ} \mathrm{N}, 26.7^{\circ} \mathrm{W}$ & $1-1642$ & $4 / y r$ & 0.212 & ECM & & this paper \\
\hline Crête & $71.1^{\circ} \mathrm{N}, 37.3^{\circ} \mathrm{W}$ & $553-1778$ & $4 / \mathrm{yr}$ & 0.267 & ECM & & this paper \\
\hline Greenland Site A & $70.8^{\circ} \mathrm{N}, 36^{\circ} \mathrm{W}$ & $1715-1985$ & $1 / \mathrm{yr}$ & 0.267 & EXS & $\mathrm{kg} / \mathrm{km}^{2}$ & Mosley-Thompson et al. [1993] \\
\hline Renland & $70.6^{\circ} \mathrm{N}, 35.8^{\circ} \mathrm{W}$ & $1000-1984$ & $1 / \mathrm{yr}$ & 0.319 & ECM & & this paper \\
\hline $20 \mathrm{D}^{\mathrm{b}}$ & $65^{\circ} \mathrm{N}, 45^{\circ} \mathrm{W}$ & $1767-1983$ & $1 / \mathrm{yr}$ & 0.410 & $\mathrm{NSS} \mathrm{SO}_{4}$ & $\mathrm{ng} / \mathrm{g}$ & Mayewski et al. [1990] \\
\hline Mount Logan ${ }^{\mathrm{b}}$ & $60.6^{\circ} \mathrm{N}, 141^{\circ} \mathrm{W}$ & $1689-1979$ & $1 / \mathrm{yr}$ & 0.330 & total $\mathrm{SO}_{4}$ & $\mu e q / L$ & Mayewski et al. [1993] \\
\hline Law Dome & $66.7^{\circ} \mathrm{S} 112.8^{\circ} \mathrm{E}$ & $1301-1995$ & $12 / \mathrm{yr}$ & 0.644 & $\mathrm{NSS} \mathrm{SO}_{4}$ & $\mu \mathrm{eq} / \mathrm{L}$ & Palmer et al. [2002] \\
\hline Dyer & $70.7^{\circ} \mathrm{S}, 65^{\circ} \mathrm{W}$ & $1505-1989$ & $1 / \mathrm{yr}$ & 0.450 & total $\mathrm{SO}_{4}$ flux & $\mathrm{kg} / \mathrm{km}^{2}$ & Cole-Dai et al. [1997] \\
\hline $\mathrm{G} 15^{\mathrm{b}}$ & $71.2^{\circ} \mathrm{S}, 46^{\circ} \mathrm{E}$ & $1210-1983$ & varies & 0.130 & DEP & $\mu \mathrm{S} / \mathrm{m}$ & Moore et al. [1991] \\
\hline Talos Dome & $72.8^{\circ} \mathrm{S}, 159.1^{\circ} \mathrm{E}$ & $1217-1996$ & varies & 0.081 & $\mathrm{NSS} \mathrm{SO}_{4}$ & $\mu e q / L$ & Stenni et al. [2002] \\
\hline Dome $C^{b}$ & $74.7^{\circ} \mathrm{S}, 124.2^{\circ} \mathrm{E}$ & $1763-1973$ & $1 / \mathrm{yr}$ & 0.031 & $\mathrm{NSS} \mathrm{SO}_{4}$ & $\mu \mathrm{eq} / \mathrm{L}$ & Legrand and Delmas [1987] \\
\hline DML_B32.SO ${ }_{4}$ & $75^{\circ} \mathrm{S}, 0^{\circ} \mathrm{W}$ & $159-1997$ & varies & 0.061 & $\mathrm{NSS} \mathrm{SO}_{4}$ & $\mathrm{ng} / \mathrm{g}$ & Traufetter et al. [2004] \\
\hline DML_B32.ECM & $75^{\circ} \mathrm{S}, 0^{\circ} \mathrm{W}$ & $159-1997$ & $12 / \mathrm{yr}$ & 0.061 & NSS-conductivity & $\mu \mathrm{S} / \mathrm{cm}$ & Sommer et al. [2000a] \\
\hline DML_B33 & $75.2^{\circ} \mathrm{S}, 6.5^{\circ} \mathrm{W}$ & $1-1996$ & $12 / \mathrm{yr}$ & 0.063 & NSS-conductivity & $\mu \mathrm{S} / \mathrm{cm}$ & Sommer et al. [2000a] \\
\hline DML_B31 & $75.6^{\circ} \mathrm{S}, 3.5^{\circ} \mathrm{W}$ & $463-1994$ & $12 / \mathrm{yr}$ & 0.044 & NSS-conductivity & $\mu \mathrm{S} / \mathrm{cm}$ & Sommer et al. [2000a] \\
\hline Siple Station & $76^{\circ} \mathrm{S}, 84.3^{\circ} \mathrm{W}$ & $1417-1983$ & $1 / \mathrm{yr}$ & 0.550 & Total $\mathrm{SO}_{4}$ flux & $\mathrm{kg} / \mathrm{km}^{2}$ & Cole-Dai et al. [1997] \\
\hline ITASE 01-5 & $77^{\circ} \mathrm{S}, 89^{\circ} \mathrm{W}$ & $1781-2002$ & varies & 0.389 & $\mathrm{SO}_{4}$ & $\mu \mathrm{g} / \mathrm{L}$ & Dixon et al. [2004] \\
\hline ITASE 00-5 & $77.7^{\circ} \mathrm{S}, 124^{\circ} \mathrm{W}$ & $1708-2001$ & varies & 0.136 & $\mathrm{SO}_{4}$ & $\mu \mathrm{g} / \mathrm{L}$ & Dixon et al. [2004] \\
\hline ITASE 00-4 & $78^{\circ} \mathrm{S}, 120^{\circ} \mathrm{W}$ & $1799-2001$ & varies & 0.190 & $\mathrm{SO}_{4}$ & $\mu \mathrm{g} / \mathrm{L}$ & Dixon et al. [2004] \\
\hline ITASE 01-3 & $78.1^{\circ} \mathrm{S}, 95.6^{\circ} \mathrm{W}$ & $1859-2002$ & varies & 0.326 & $\mathrm{SO}_{4}$ & $\mu \mathrm{g} / \mathrm{L}$ & Dixon et al. [2004] \\
\hline ITASE 00-1 & $79.4^{\circ} \mathrm{S}, 111^{\circ} \mathrm{W}$ & $1651-2001$ & varies & 0.218 & $\mathrm{SO}_{4}$ & $\mu \mathrm{g} / \mathrm{L}$ & Dixon et al. [2004] \\
\hline ITASE 99-1 & $80.6^{\circ} \mathrm{S}, 122.6^{\circ} \mathrm{W}$ & $1713-2000$ & varies & 0.130 & $\mathrm{SO}_{4}$ & $\mu \mathrm{g} / \mathrm{L}$ & Dixon et al. [2004] \\
\hline Plateau Remote ${ }^{\mathrm{b}}$ & $84^{\circ} \mathrm{S}, 43^{\circ} \mathrm{E}$ & $1-1986$ & $1 / \mathrm{yr}$ & 0.040 & $\mathrm{SO}_{4}$ & ppb & Cole-Dai et al. [2000] \\
\hline $\mathrm{PS} 1^{\mathrm{b}}$ & $90^{\circ} \mathrm{S}$ & $1010-1984$ & $1 / \mathrm{yr}$ & 0.080 & $\mathrm{NSS} \mathrm{SO}_{4}$ & $\mathrm{ng} / \mathrm{g}$ & Delmas et al. [1992] \\
\hline $\mathrm{PS} 14^{\mathrm{b}}$ & $90^{\circ} \mathrm{S}$ & $1800-1984$ & $1 / \mathrm{yr}$ & 0.080 & $\mathrm{NSS} \mathrm{SO}_{4}$ & $\mathrm{ng} / \mathrm{g}$ & Delmas et al. [1992] \\
\hline SP2001c1 & $90^{\circ} \mathrm{S}$ & $905-1999$ & $1 / \mathrm{yr}$ & 0.080 & Total $\mathrm{SO}_{4}$ flux & $\mathrm{kg} / \mathrm{km}^{2}$ & Budner and Cole-Dai [2003] \\
\hline SP95 & $90^{\circ} \mathrm{S}$ & $1487-1992$ & varies & 0.078 & $\mathrm{SO}_{4}$ & $\mu \mathrm{g} / \mathrm{L}$ & Dixon et al. [2004] \\
\hline
\end{tabular}

${ }^{a}$ ECM, electrical conductivity measurement; DEP, dielectric profiling; NSS SO4, non-sea-salt sulfate; CFA, continuous flow analysis; NSS-conductivity, non-sea-salt conductivity; EXS, excess sulfate; mwe, meters of liquid water equivalent.

${ }^{\mathrm{b}}$ Ice cores used by Robock and Free [1995].

volcanic signal. For example, the sulfate flux of the Kuwae eruption derived from Plateau Remote is five times that of the Tambora [Cole-Dai et al., 2000], which raises the question about the relative magnitude of the Kuwae and other large volcanic eruptions during the past 2000 years. Because of different site characteristics, such as the relative contribution of different air-to-snow mass transfer mechanisms (wet and dry deposition, riming, and vapor transfer) of sulfate aerosols as well as the surface elevation and irregularities, temperatures, wind speed that affect the flux of sulfate aerosols [Cole-Dai et al., 1997] and thus the magnitude of volcanic signals, studies based on multiple ice cores from both Antarctic and Greenland are required to better understand this problem, as suggested by previous studies [Robock and Free, 1995; Free and Robock, 1999; Mosley-Thompson et al., 2003].

[3] In our study, we have incorporated the volcanic signals derived from 33 ice core records from both hemispheres to determine the timing and magnitude of the Kuwae eruption. Results obtained from these multiple ice cores reevaluate and complement the previous geological, historical and proxy data. The estimated timing of the eruption not only provides a tool to evaluate the dating of existing ice core record serves as a volcanic reference horizon for future ice core dating and important case study for the effects of volcanic eruptions on climate change.

\section{Ice Core Database and Volcanic Signal Extraction Methods}

[4] After large explosive volcanic eruptions, a portion of emitted sulfate aerosols is embedded and preserved in certain glaciers and ice sheets, in the snow and ice by precipitation or by dry deposition. Thus measurement of the total acidity or the actual sulfate content in the ice cores from those areas allows relatively precise computation of a volcanic time series [Robock and Free, 1995, 1996; Robock, 2000]. While no individual ice core record is representative of past volcanism due to the large spatial variation of volcanic deposition on ice sheets [Zielinski et al., 1997], previous studies [Robock and Free, 1995; Free and Robock, 1999] suggested that results compiled from multiple ice cores can reduce the errors associated with individual records and provide a more reliable index of past volcanism. In our study, we used 33 ice cores, 13 in the $\mathrm{NH}$ and 20 in the Southern Hemisphere (SH). Table 1 lists the names and general information about these 33 ice cores, among which 19 ice cores, 10 in the $\mathrm{SH}$ and nine in the $\mathrm{NH}$, contain data 


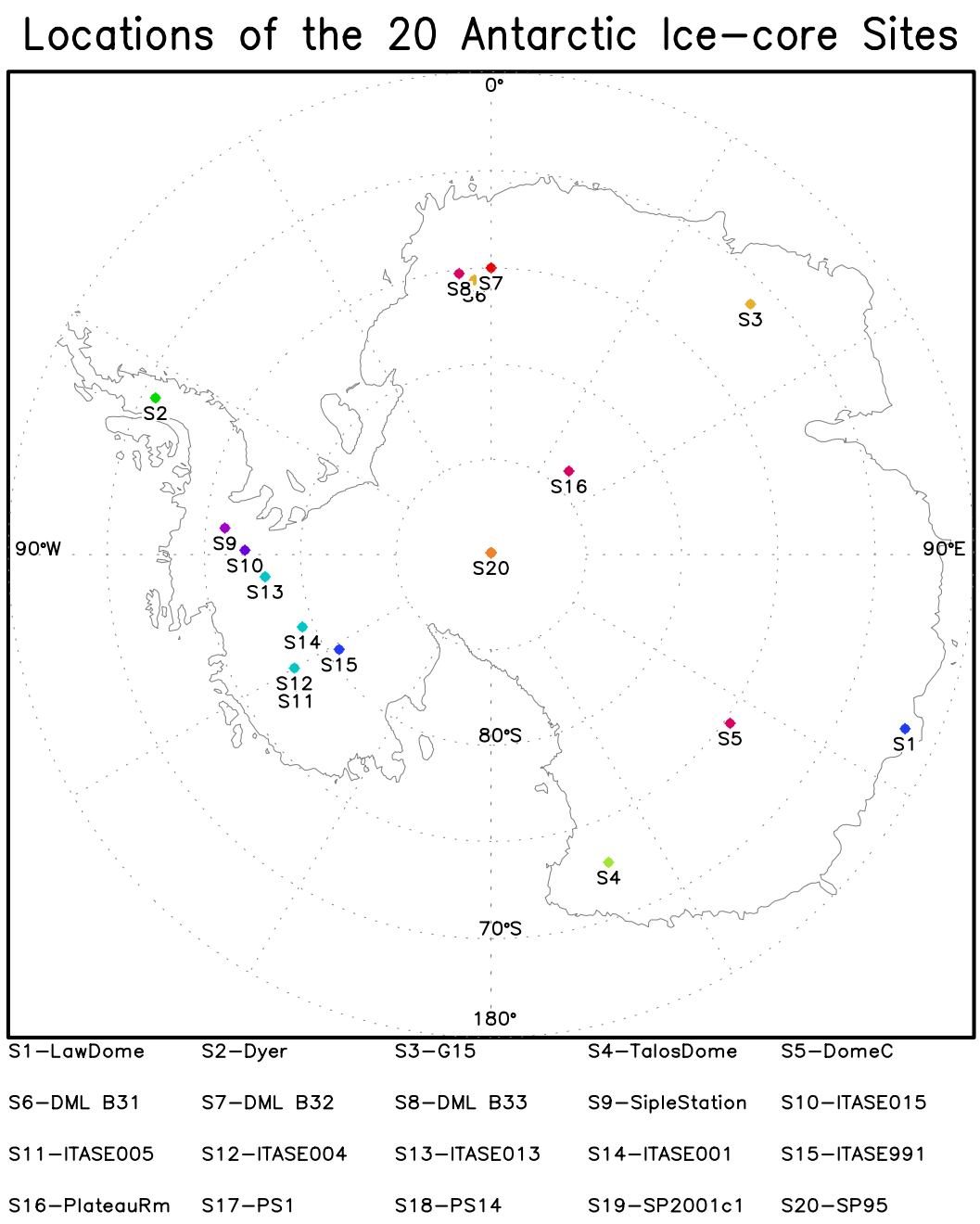

Note: Sites S17 - S20 are at the same location.

Figure 1. Locations of the 20 Southern Hemisphere ice core sites (see Table 1).

beginning in or before the 15th century. From Table 1 we also see that 24 ice cores, 17 in the $\mathrm{SH}$ and seven in the $\mathrm{NH}$, have sulfate records. Among the 24 sulfate ice core records, only nine (7 SH, $2 \mathrm{NH}$ ) have records that go back to the 15 th century. In this study, we used all available ice cores (i.e., the 19 records with Kuwae signals) to determine the timing of the Kuwae eruption, but only the sulfate records (i.e., the nine cores with Kuwae sulfate records) to estimate the deposition of the eruption on the Antarctic and Greenland ice sheets. The estimated deposition was evaluated and adjusted with the 24 total ice core sulfate records. The reason we choose not to use electrical conductivity measurement $(\mathrm{ECM})$ records in calculating the volcanic deposition is that ECM measures acidity caused not only by sulfuric acid $\left(\mathrm{H}_{2} \mathrm{SO}_{4}\right)$, but also by nitric $\left(\mathrm{HNO}_{3}\right)$, hydrochloric $(\mathrm{HCl})$, and hydrofluoric $(\mathrm{HF})$ acids, can be reduced by deposition of basic (as contrasted with acidic) aerosol particles, and depends on the temperature at the time when the measurement was taken. Figures 1 and 2 show the locations of these 33 sites, except the Mount Logan ice core which is far away from Greenland. We can see from Figures 1 and 2 that the 19 sites with Kuwae signals are relatively evenly distributed in both regions, especially for the 10 ice cores in $\mathrm{A}$ ca.
[5] To extract the volcanic signals from the annual average time series of each ice core we used the following procedures: (1) convert the sulfate concentration time series into fluxes (see Appendix A), (2) remove the trend and the background variation with a high-pass loess filter, a locally weighted least squares quadratic estimate [Cleveland and Devlin, 1988], to remove signals longer than 31 years, (3) calculate the 31 year running median absolute deviation (MAD) of the residuals and select the potential volcanic peaks if they exceed the baseline plus 2 running MAD, (4) replace the selected peak values with the median of the original time series, (5) repeat step 2 using the time series with the peaks removed, and (6) repeat step 3 to extract the volcanic peaks. We use the loess filter and MAD because they provide robust estimates for a wide range of population distributions, and do not require a normal distribution, which is the underlying assumption for the automatic extraction method [Naveau et al., 2003] and other methods [e.g., Robock and Free, 1995, 1996] that extract peaks above a certain standard deviation limit. We chose an appropriate window length and extraction threshold by examining the properties of the detrended, peak-removed residuals such as normality, constant variance, and minimum autocorrelation. On the basis of 


\section{Locations of the $12 \mathrm{NH}$ Ice-core Sites}

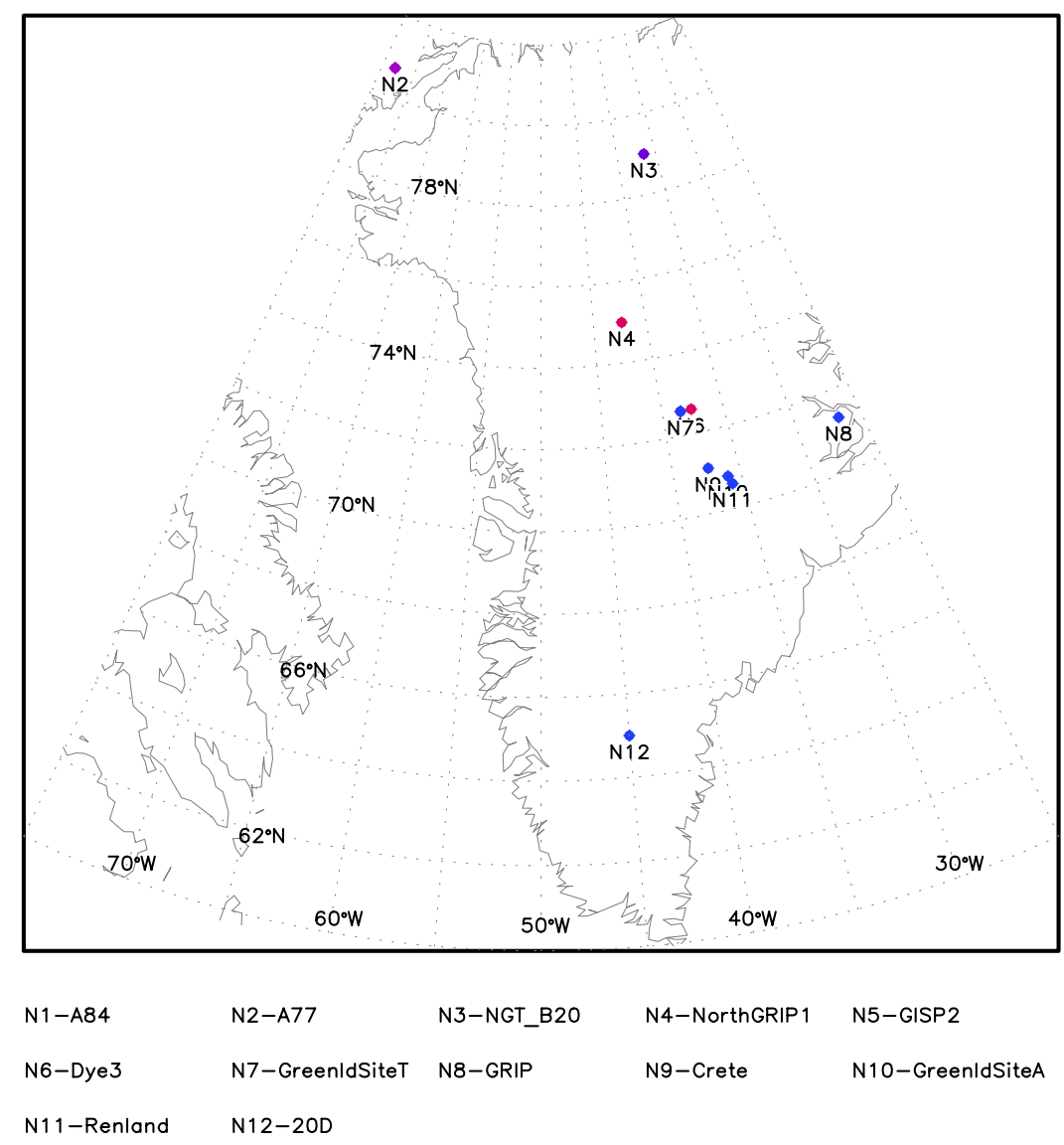

Note: sites $N 1 \& N 2, N 5 \& N 7, N 9 \& N 10$ are at similar locations

Figure 2. Locations of 12 Northern Hemisphere ice core sites (see Table 1). Mount Logan is omitted from the map to expand Greenland where most cores are located.

spectral analysis of several of the time series, the 31 year filter falls at a spectral gap, which removes long-term variations while allowing for the full strength of volcanic peaks. For volcanic events as large as the Kuwae eruption, the choice of extraction method and criteria does not affect the results. However, for small eruptions, a suitable threshold and a robust method that is resistant to the outliers are essential in extracting the signals. To be consistent with other studies that reconstruct the entire volcanic time series, we keep the same extraction procedure here even though some steps and criteria are not critical.

\section{Timing of the Great Kuwae Eruption}

[6] Figure 3 shows the time series of the potential volcanic peaks extracted from the $10 \mathrm{SH}$ ice core records for the period 1440-1465. On the basis of previous studies, we would expect the ice core signal of a tropical eruption to show up 1-2 years after the eruption [Cole-Dai and Mosley-Thompson, 1999; Legrand and Wagenbach, 1999]. As the Kuwae caldera is located in the SH, we would expect to see the stratospheric aerosols confined mostly to the $\mathrm{SH}$ and to see its signature in $\mathrm{SH}$ ice much more strongly than in the NH.
[7] We can see in Figure 3 that two records (Siple Station, DML_B31) show large peaks during the period 14541456; and three records (Talos Dome, DML B32 and DML_B33) have peaks during 1453-1456. All of these five cores [Cole-Dai et al., 1997; Sommer et al., 2000b; Stenni et al., 2002; Traufetter et al., 2004] were absolutely dated by counting seasonal cycles of non-sea-salt $\mathrm{SO}_{4}^{2-}$, $\delta^{18} \mathrm{O}$, sodium, calcium, and/or ammonium concentrations. The dating was then evaluated and refined by looking at radionuclide and volcanic markers, usually the 1259 unknown eruption, Tambora in 1815, and Agung in 1963. However, in the Talos Dome the Kuwae eruption was set to the year AD 1452 and used as a reference horizon [Stenni et al., 2002]; in the DML_B31 and DML_B33 records the peak of Kuwae signals were fixed to the year 1455 [Sommer et al., 2000b]. Ice core records dated by multiple layer accounting are considerably more accurate, though accumulated dating errors up to $1-3$ years do exist due to some ambiguous layers.

[8] Among the rest of the ice core records, SP2001c1 [Budner and Cole-Dai, 2003] has a big signal during 14561458. Accounting for a possible dating error of up to \pm 4 years, the timing of the Kuwae deposition could lie somewhere between 1452 and 1462. The peak in Plateau Remote spans 1451-1455 in Figure 3. This core was dated using an 


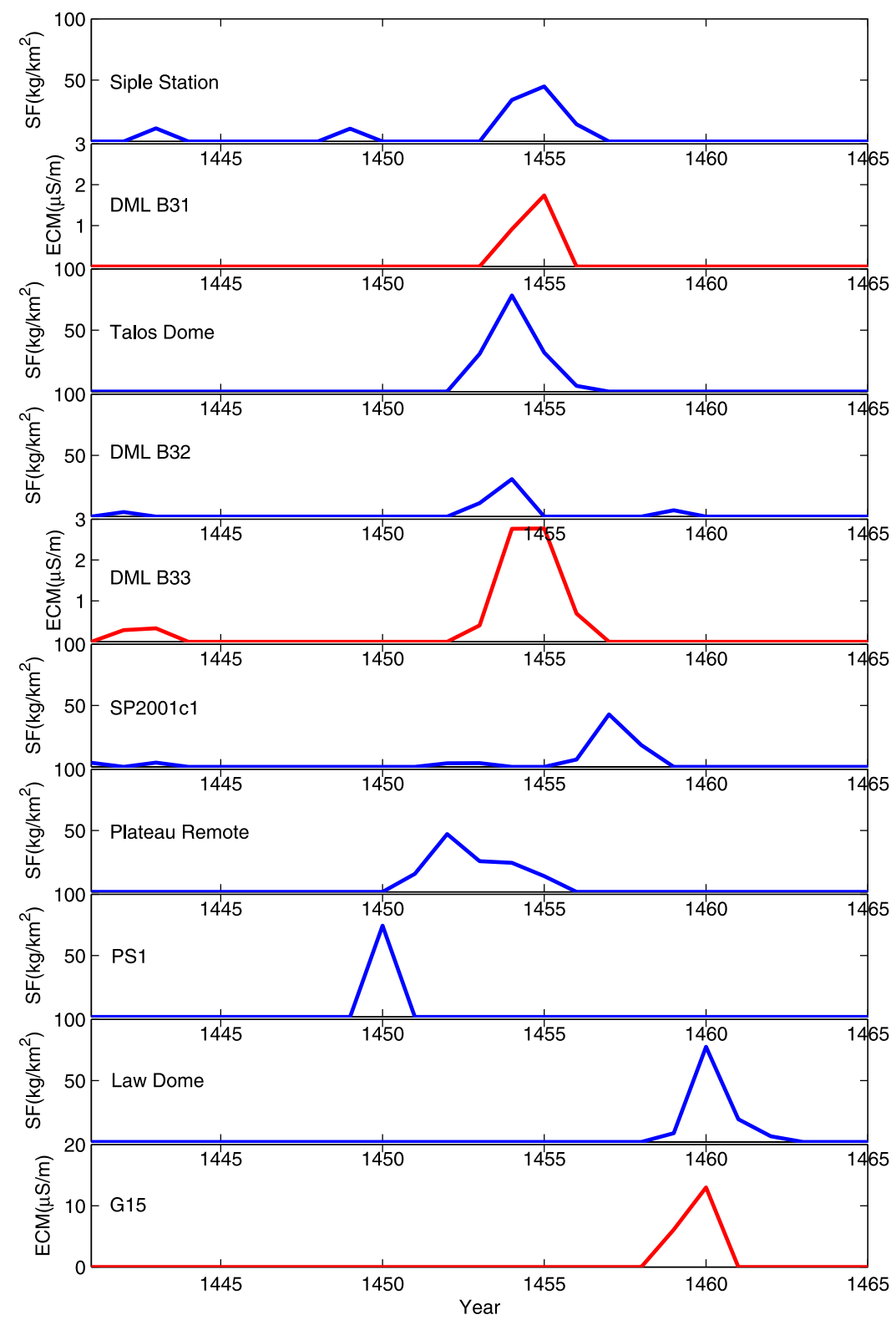

Figure 3. Kuwae signals extracted from the annual time series of the 10 Southern Hemisphere ice core records (see Table 1 and Figure 1). SF (in blue) is sulfate flux and ECM (in red) is electrical conductivity measurement.

age model and the Kuwae peak was fixed to 1454 and served as a reference horizon [Cole-Dai et al., 2000]. The Law Dome record [Palmer et al., 2002] was composited from three ice cores, DSS97 (1888-1995), DSS99 (18411888), and DSS (1301-1841), which may cause either missing or faulty annual layers at the conjunctions. Thus it is possible for the peak shown at 1460 in Figure 3 to be off by a few years. The PS1 data we have only contain volcanic signals extracted by the authors [Delmas et al., 1992], and it has a single value for each event though the authors stated that the Kuwae deposition lasted for 3 full years. The dating uncertainty is \pm 10 years during the period from 1259 to 1800 and the authors "redate" the Kuwae event to the year 1452 according to tree ring evidence [ $\mathrm{La}$ Marche and Hirschboeck, 1984]. G15 [Moore et al., 1991] was dated by first usi ung, Tambora and the 1259 unknown to fix the chronology and then interpolating between these events. Therefore it is possible that the timing of Kuwae as interpreted from this core was off by several years. In general, the $\mathrm{SH}$ ice core records seem to suggest a 3-4 year Kuwae deposition at about 1453-1456.

[9] Evidence from $\mathrm{NH}$ ice core records is less clear. As shown in Figure 4 several of the NH ice core records show double peaks during the period from 1450 to 1465 , with one in the mid-1450s and the other at the beginning of $1460 \mathrm{~s}$. No signal was detected in the GRIPmain ice core records. Previous studies [Fisher et al., 1985; Langway et al., 1995] suggest that the Crête ice core has a high dating accuracy due to the low signal-to-noise variance ratios in terms of both accumulation rate and layer separation, plus there is virtually no melting in this site. We extracted a large acid spike during 1453-1454 in the Crête ECM record. Ac- 


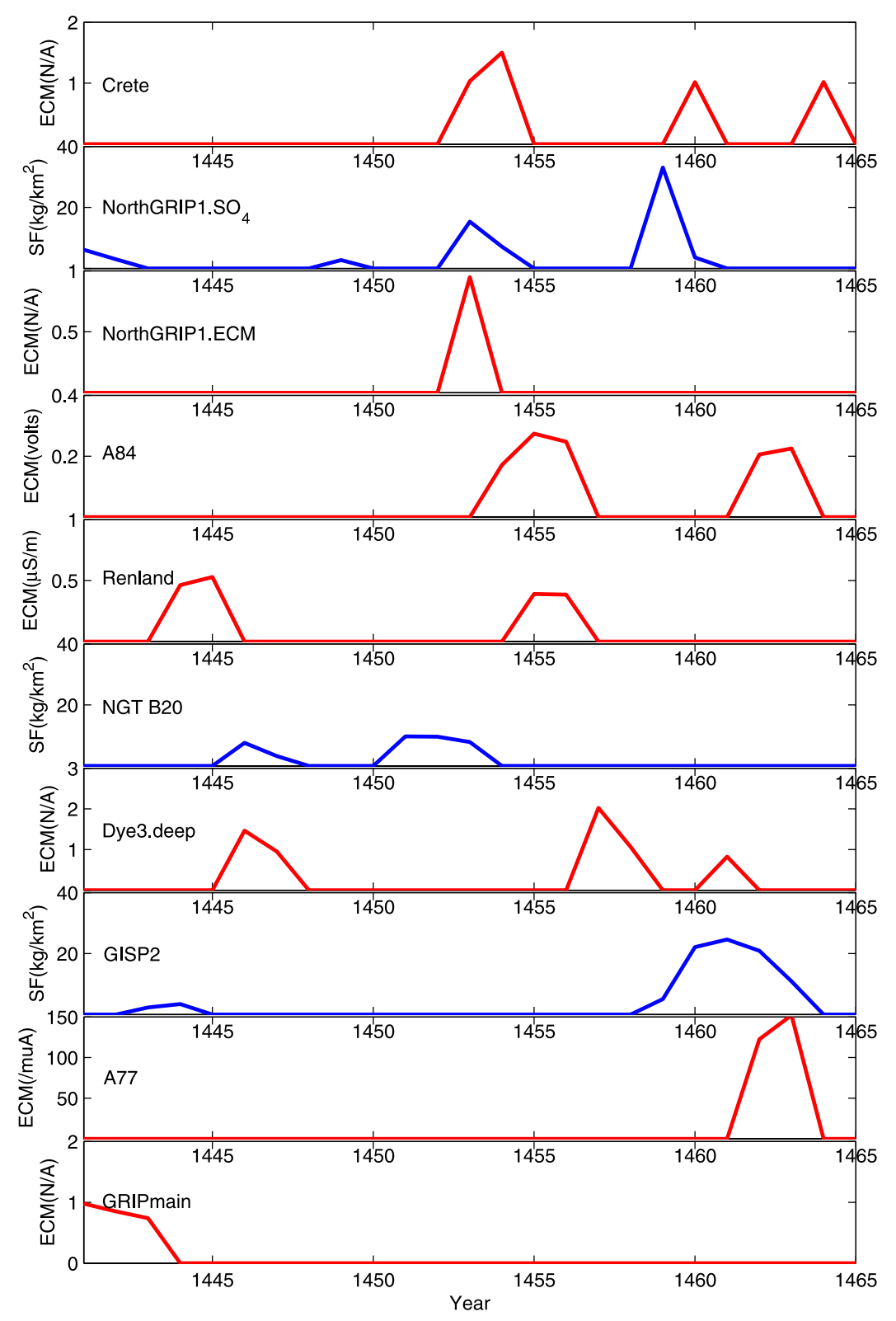

Figure 4. Kuwae signals extracted from the annual time series of the 10 Northern Hemisphere ice core records (see Table 1 and Figure 2). SF (in blue) is sulfate flux, and ECM (in red) is electrical conductivity measurement.

counting for the $\pm 1-2$ year dating error [Hammer et al., 1980], this result suggests a Kuwae deposition during 1451-1456. Other NH ice core records that have a signal during this period are A84, Renland, and both of the NorthGRIP1 sulfate and ECM data. NGT_B20 [Bigler et al., 2002] was dated based on identification of the wellknown historical volcanic layers (Katmai 1912, Tambora 1815, Laki 1783, Huaynaputina 1600, unknown 1259, and Eldgjá 934) plus annual counting using the seasonal variation of calcium and sodium. The dating accuracy is \pm 5 years, which places the Kuwae signal in the time interval 1446-1458. In the GISP2 record a larger signal was detected during 1458-1461. The volcanic signals in GISP2 are generally spread due to the biyearly sampling scheme used so the original signal is probably only in 1459-1460.
Zielinski [1995] assigned this signal to the Kuwae eruption. Here we suggest that this $1459-1460$ peak is the deposition of a local eruption at the beginning of 1460s rather than Kuwae for the following two reasons. First, we found an almost constant dating error of $-1-2$ years (i.e., 1 or 2 years earlier than the actual date) in GISP2 by comparing its volcanic signals with the other cores and the historical documents; therefore it is unlikely that this signal represents the deposition of Kuwae eruption found to be in the middle 1450 s, based on our SH ice cores results. Second, several other NH ice cores, such as the Crête, NorthGRIP1 sulfate, A77, A84, and Dye3 deep records (Figure 4), also have separate peaks during the same period that are not due to the Kuwae aerosols. The missing of Kuwae signal in both the GISP2 and GRIPmain ice core record may be a result of 
Table 2. Average Total Sulfate Depositions and the Corresponding Standard Deviations Based on Different Groups of Ice Cores for the Laki, 1809 Unknown, Tambora, and Krakatau Eruptions ${ }^{\text {a }}$

\begin{tabular}{|c|c|c|c|c|c|c|c|c|}
\hline Volcano & Latitude & Year & $7 \mathrm{SH}$ & $17 \mathrm{SH}$ & $2 \mathrm{NH}$ & $7 \mathrm{NH}$ & PARCA & CH1988 \\
\hline Kuwae & $17^{\circ} \mathrm{S}$ & 1452 & $93.0 \pm 35.5$ & $97.7^{\mathrm{b}}$ & $24.8 \pm 3.2$ & $44.6^{\mathrm{b}}$ & N/A & N/A \\
\hline Laki & $64^{\circ} \mathrm{N}$ & 1783 & N/A & N/A & $87.6 \pm 4.2$ & $103.2 \pm 35.1$ & $187.0 \pm 91.8$ & $171.3 \pm 72.5$ \\
\hline Unknown & tropical? & 1809 & $25.1 \pm 13.3$ & $27.2 \pm 12.3$ & $17.7 \pm 19.2$ & $25.9 \pm 15.2$ & $35.9 \pm 8.8$ & N/A \\
\hline Tambora & $8^{\circ} \mathrm{S}$ & 1815 & $56.7 \pm 32.8$ & $59.4 \pm 26.4$ & $31.3 \pm 8.5$ & $49.5 \pm 24.8$ & $60.4 \pm 16.9$ & $64.2 \pm 33.1$ \\
\hline Krakatau & $6^{\circ} \mathrm{S}$ & 1883 & $12.4 \pm 5.6$ & $12.1 \pm 5.9$ & $4.6 \pm 0.6$ & $14.0 \pm 7.4^{\mathrm{c}}$ & N/A & N/A \\
\hline
\end{tabular}

${ }^{a}$ All values are calculated in the same way. The 7 Southern Hemisphere (SH) cores: SP2001, PS1, Plateau Remote, Talos Dome, Law Dome, Siple Station, and B32. The 17 SH cores: the above seven cores plus SP95, ITASE015, ITASE005, ITASE004, ITASE013, TASE001, ITASE991, Dyer, Dome C, and PS14. The 2 Northern Hemisphere (NH) cores: B20 and NorthGRIP1. The 7 NH cores: the above two cores plus Greenland Site A and T, GISP2, 20D, Mount Logan. See Table 1 for details on these cores. PARCA data from four cores (GITS, D2, D3, and Raven) for unknown and Tambora and five cores (D2, D3, Raven, Humboldt, and NASA-U) for Laki are from Table 2 of Mosley-Thompson et al. [2003]. CH1988 data obtained by averaging the sulfate depositions of 12 and $11 \mathrm{NH}$ cores from Table 4 of Clausen and Hammer [1988]. Deposition values are in $\mathrm{kg} / \mathrm{km}^{2}$.

${ }^{\mathrm{b}}$ These are estimated values by multiplying the Kuwae deposition in columns 4 and 6 with the average ratios of 7 versus $17 \mathrm{SH}$ and 2 versus $7 \mathrm{NH}$ ice core mean depositions, respectively. Thus these two values roughly represent the average Kuwae depositions if all of the $17 \mathrm{SH}$ and $7 \mathrm{NH}$ ice cores were available.

${ }^{c}$ The Krakatau signal does not show in the Mount Logan ice core record. Therefore the total deposition for the Krakatau eruption is averaged over six NH ice core records instead of seven.

the natural spatial variation of volcanic deposition; or it may be caused by the loss of snow and ice during the postdepositional redistribution or even the drilling and handing processes.

[10] All of the ten $\mathrm{SH}$ ice core records in Figure 3 display only one dominant peak during the interval 1445-1465, suggesting that the Kuwae eruption was a single-phase volcanic event. The multiple peaks shown in some of the NH time series (Figure 4) were probably caused by signals from other sources such as local volcanic eruptions. Since the Kuwae eruption is at $17^{\circ} \mathrm{S}$, it is reasonable to base our analysis on the $\mathrm{SH}$ ice core records and conclude that the eruption was indeed a single-phase event.

[11] In summary, the ice core records support the previous discovery that there was a large volcanic eruption somewhere during the 1450s that emitted significant amounts of sulfate aerosols into both hemispheres. Although signals derived from individual ice cores indicate different timings of the Kuwae eruption, when accounting for the dating errors associated with each record, these signals seem to point to a volcanic deposition during the period 1453-1457, suggesting that the Kuwae eruption took place in either late 1452 or early 1453 . This result is consistent with previous suggestions based on the geological record [Simkin and Siebert, 1994], historical records [Pang, 1993; Simarski, 1996], and proxy data [La Marche and Hirschboeck, 1984; Pang, 1993; Briffa et al., 1998].

\section{Sulfate Deposition}

[12] To calculate the amount of sulfate deposited in the polar regions by the Kuwae eruption, we first adjusted the timing of the Kuwae signals in each ice core record by lining them up during 1453-1456 and fixing the highest values at year 1454. We then calculated the hemispheric average sulfate deposition based on the seven $\mathrm{SH}$ ice cores (SP2001c1, PS1, Plateau Remote, Talos Dome, Law Dome, Siple Station, and DML_B32) and two NH ice cores (NGT_B20 and NorthGRIP1) that have sulfate records. The resulting total sulfate deposition was $93.0 \mathrm{~kg} \mathrm{SO} / \mathrm{km}^{2}$ and $24.8 \mathrm{~kg} \mathrm{SO} \mathrm{SO}_{4} / \mathrm{km}^{2}$ for $\mathrm{SH}$ and $\mathrm{NH}$ ice core records, respectively (Table 2 ). The difference between these two average values suggests an asymmetric distribution of the volcanic debris.

[13] To evaluate how representative these seven $\mathrm{SH}$ and two NH ice core records are, we compared the average sulfate depositions derived from these records to those from a larger number of ice cores for several other well-known volcanic events when more ice core records were available. In the $\mathrm{SH}$ we calculated sulfate deposition averaged from the seven cores and those from 17 records for the 1809 unknown, 1815 Tambora, and 1883 Krakatau eruptions. These results, together with those for the NH ice core comparisons, are shown in Table 2. We also plotted in Figure 5 the sulfate fluxes averaged over the seven versus $17 \mathrm{SH}$ ice cores and two versus seven $\mathrm{NH}$ ice cores, respectively, for the four years following the Tambora eruption. Our results show that the sulfate fluxes based on these seven $\mathrm{SH}$ ice cores records are very close, within $5 \%$, to those from $17 \mathrm{SH}$ records for the five events chosen. Therefore it is reasonable to assume that our estimation of sulfate fluxes for the Kuwae eruption based on the seven $\mathrm{SH}$ cores is representative of what we would obtain from the $17 \mathrm{SH}$ ice core records.

[14] Similarly, we calculated the average sulfate deposition of the two Greenland cores and the total seven cores for the Laki, 1809 unknown, 1815 Tambora, and 1883 Krakatau eruptions (Table 2). The results based on the two northern Greenland ice core records are smaller than those averaged over the seven Greenland cores. Also listed in Table 2 are the average sulfate depositions for the unknown, Tambora, and Krakatau eruptions from six Program for Arctic Regional Climate Assessment (PARCA) [MosleyThompson et al., 2003] ice cores, and 12 Greenland cores from Clausen and Hammer [1988]. We can see that for all of the three events, the average sulfate deposition of these two other groups of Greenland ice core records is about twice as large as those of the two NH records. Previous studies [e.g., Zielinski et al., 1997] found that there are large spatial variations in the volcanic depositions among different $\mathrm{NH}$ ice cores. We also found, for instance, that the Tambora deposition ranges from $25 \mathrm{~kg} / \mathrm{km}^{2}$ in B20 $\left(79^{\circ} \mathrm{N}\right)$ to $73 \mathrm{~kg} / \mathrm{km}^{2}$ in GISP2 $\left(72.6^{\circ} \mathrm{N}\right)$ and $85 \mathrm{~kg} / \mathrm{km}^{2}$ in $20 \mathrm{D}$ $\left(65^{\circ} \mathrm{N}\right)$. Since both NGT_B20 and NorthGRIP1 $\left(75.1^{\circ} \mathrm{N}\right)$ 

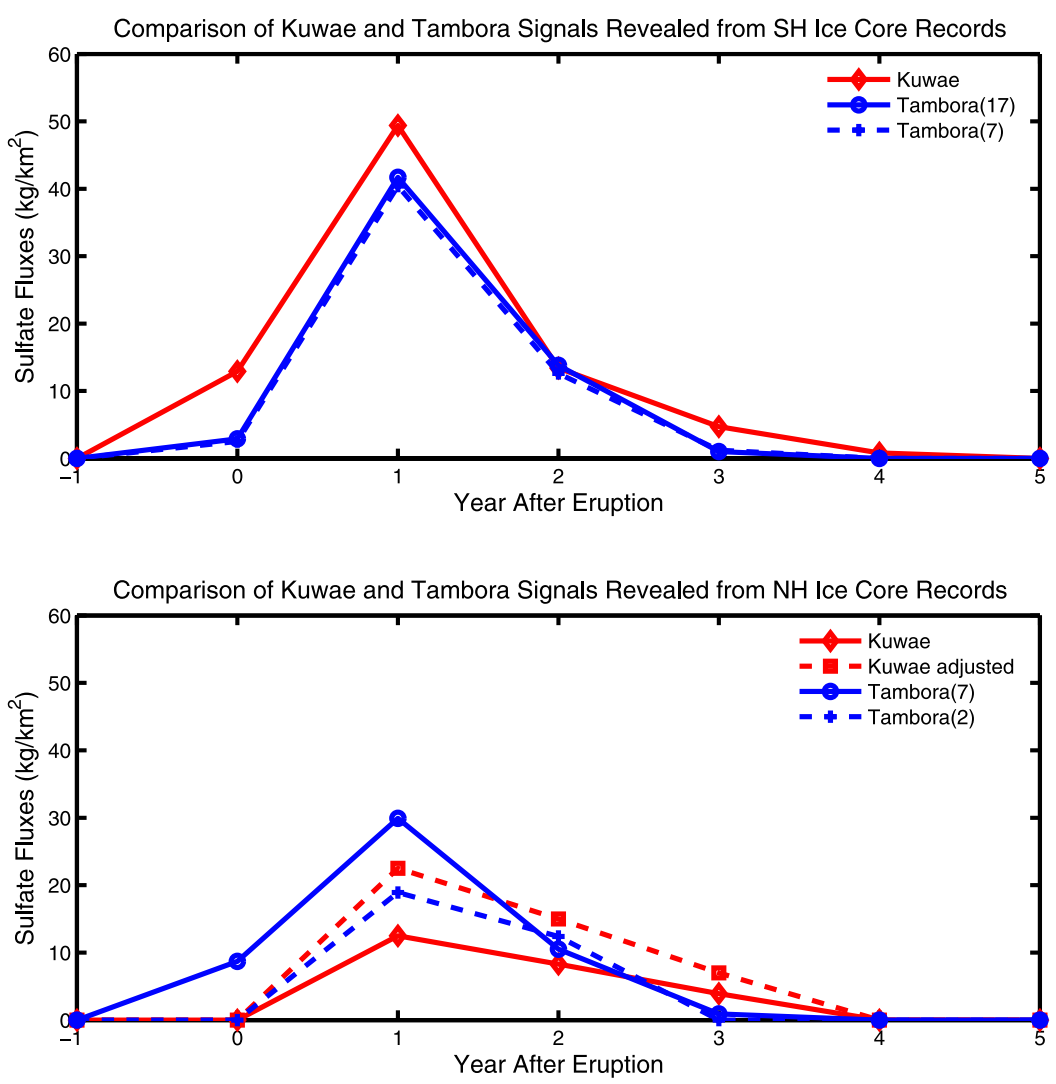

Figure 5. Comparison of the Kuwae and Tambora signals revealed from the ice core records. The eruption year was set to be 1452 and 1815 for Kuwae and Tambora, respectively, and the signals were adjusted to have the peak values line up in the year after eruption. Two sets of Tambora results were plotted for each hemisphere, one averaged over all the cores available and the other averaged over the same cores as Kuwae. The adjusted estimation (see text for details) of Kuwae deposition is also plotted.

are located in northern Greenland with very low accumulation rates (10 and $15 \mathrm{~cm}$ water equivalent per year, respectively) we speculate that this is the major reason why the average deposition from these two records is smaller than that derived from the seven records in our study and the two other groups of Greenland records. To make the estimation of Kuwae deposition representative of the entire Greenland, we first calculated the ratio of average deposition from the total seven $\mathrm{NH}$ cores to those from these two cores for the four later eruptions and obtained the average ratio of 1.8, which is close to the ratio obtained from the two other groups of Greenland records as mentioned above. Then, we adjust the estimation of Kuwae deposition by multiplying the Kuwae deposition obtained from the $2 \mathrm{NH}$ ice cores by a factor of 1.8 and obtained a deposition of $44.6 \mathrm{~kg} \mathrm{SO} / \mathrm{km}^{2}$. The adjusted result is listed in Table 2 and also plotted in Figure 5. If we apply the same procedure to the $\mathrm{SH}$, we obtain the adjusted estimation of Kuwae deposition in the Antarctic of $97.7 \mathrm{~kg} \mathrm{SO} / \mathrm{km}^{2}$, which is very close to our original estimation.

[15] Comparing the sulfate deposition of Kuwae eruption to that for the Tambora eruption (Figure 5 and Table 2) we find that the magnitude of the Kuwae deposition is smaller than that for Tambora for the NH, but much larger for the $\mathrm{SH}$. The greater hemispheric asymmetry of Kuwae as compared to Tambora is reasonable given that Kuwae $\left(17^{\circ} \mathrm{S}\right)$ is much farthe the Equator than Tambora $\left(8^{\circ} \mathrm{S}\right)$. On the other hand, besides the location of an eruption, the distribution of volcanic debris also depends heavily on the time of the year when the eruption took place, the location of the Intertropical Convergence Zone, the Quasi-Biennial Oscillation, and the stratospheric winds on the day of the eruption. These factors introduce an uncertainty when trying to estimate hemispheric loading from an eruption, but if we know the deposition, we can infer stratospheric loading for each hemisphere. This is illustrated by the 1963 Agung eruption, which occurred at $8^{\circ} \mathrm{S}$, the same latitude as Tambora, but also dispersed two thirds of its volcanic aerosols into the SH, the same proportion as Kuwae, but different to that of Tambora's aerosols which were more evenly distributed.

[16] Table 2 also shows the standard deviations of volcanic sulfate deposition for each eruption, from which we can see that there are large spatial variations in both Antarctic and Greenland ice cores. Several factors can account for this variation, such as surface irregularity, elevation, temperature, wind redistribution, and relative contribution of wetdry deposition. Figure 6 shows the ratios between the net deposition of Kuwae and Tambora sulfate aerosols. The use of these ratios eliminates much of the intersite variability described above [Cole-Dai et al., 1997]. However, Plateau Remote still has an unusually large ratio (5.6) followed by Talos Dome (3.8), compared with the average ratio (1.1) of the other six ice cores. Cole-Dai et al. [2000] suggested that 


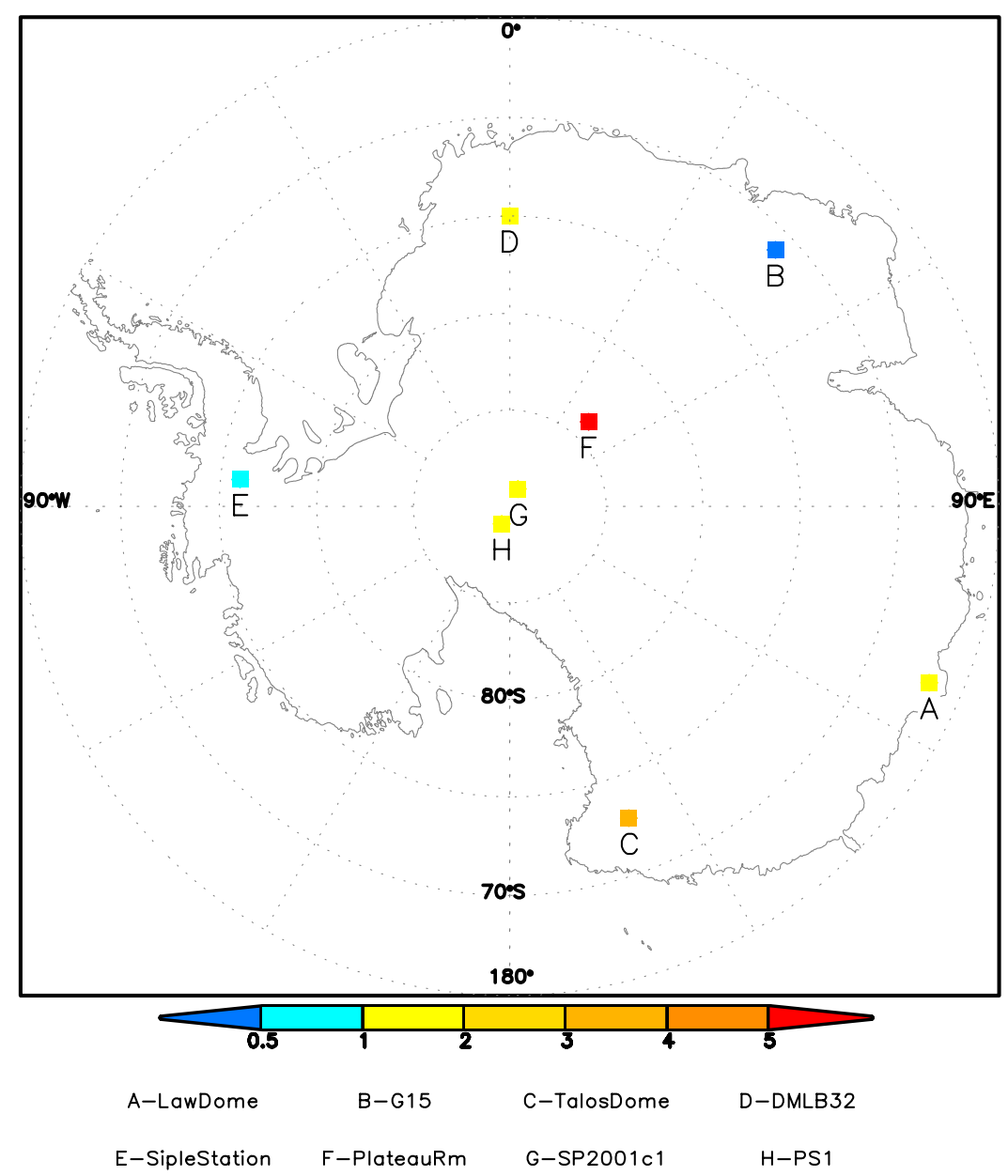

Figure 6. Spatial distribution of the ratio between the net deposition for Kuwae and Tambora eruption in eight Antarctic ice cores.

the high value in Plateau Remote was caused by the partial loss or gain of snow within annual layers, whose effects are more pronounced in the low-accumulation sites; whereas Castellano et al. [2005] speculated that the Kuwae distribution pattern can be a real spatial variation in its depositional fluxes. The high ratios in these two sites doubled the overall average ratio between Kuwae and Tambora, and our results may overestimate the mean Kuwae sulfate deposition in Antarctica if the high ratios in the above two sites are actually caused by net gain of snow. This once again addresses the importance of using multiple (as many as available) ice cores with full spatial coverage to obtain the forcing index of past volcanism.

\section{Conclusions}

[17] We have used 33 ice core records, 13 from the Northern Hemisphere and 20 from the Southern Hemisphere, to examine the timing and magnitude of the great Kuwae eruption in the mid-15th century. Our results suggest that the Kuwae eruption is a single-phase eruption which took place in late 1452 or early 1453 , producing significant depositions that lasted up to four years in both Greenland and Antarctic ice sheets. The Kuwae signals detected in ice cores from both polar regions confirm the potential of this eruption for global climatic impacts. The large difference between the two hemispheric-average sulfate deposition densities $\left(97.7 \mathrm{~kg} / \mathrm{km}^{2}\right.$ in the $\mathrm{SH}$ versus $44.6 \mathrm{~kg} / \mathrm{km}^{2}$ in the $\mathrm{NH}$ ) indicates an asymmetric distribution of the volcanic debris between the two hemispheres. Our results also suggest that the Kuwae eruption caused one of the largest aerosol events in the past 700 years, probably surpassing the magnitude of the aerosol cloud caused by Tambora eruption in 1815 .

[18] Witter and Self [2006] calculated the total atmospheric sulfate aerosol loading from the Kuwae eruption and found it to lie somewhere between 235 and $414 \mathrm{Tg}$. They used geological techniques to estimate the amount of sulfur the eruption actually injected into the stratosphere. By measuring the amount of sulfate that was deposited in ice cores, in theory one could do an inverse calculation to estimate the stratospheric loading, and then use this information to calculate the radiative forcing of the climate system [e.g., Stenchikov et al., 1998], one of the ultimate goals of our research. However, to do this inverse calculation, one would have to explicitly model the stratospheric, cross-tropopause, and then tropospheric transport; microphysical, precipitation, and deposition mechanisms; as well as effects of sastrugi on 
the ice; and no one has done such a calculation yet. That work is currently underway and will be reported in a subsequent paper.

\section{Appendix A}

[19] Procedure to calculate sulfate fluxes for ice cores with sulfate concentration records.

\section{A1. Cores With Sulfate Contents in $\mu \mathrm{eq} / \mathrm{L}$}

[20] 1. Assume the density of the sample solution is similar to that of water, i.e., $1 \mu \mathrm{eq} \mathrm{SO}_{4} / \mathrm{L} \approx 1 \mu \mathrm{eq} \mathrm{SO}_{4} / \mathrm{kg}$.

[21] 2. Use $1 \mathrm{~kg} / \mathrm{L}$ as the density if the accumulation is in water equivalent, and $0.85 \mathrm{~kg} / \mathrm{L}$ as the density if the accumulation is in ice equivalent.

[22] 3. Multiply the sulfate content (in $\mu \mathrm{eq} / \mathrm{kg}$ ) with the factor $\left[L=48\left(\mathrm{~g} / \mathrm{eq} \mathrm{SO}_{4}^{2-}\right) \times\right.$ annual accumulation $(\mathrm{m} / \mathrm{yr}$ in either water or ice equivalents) $\times$ water or ice density (in $\mathrm{kg} / \mathrm{L})]$ or $\left[L=48\left(\mathrm{~g} / \mathrm{eq} \mathrm{SO}_{4}^{2-}\right) \times\right.$ annual accumulation in $(\mathrm{g}$ $\left.\mathrm{cm}^{-2} \mathrm{yr}^{-1}\right)$ or $\left.\left(\mathrm{kg} / \mathrm{km}^{2} \mathrm{yr}\right)\right]$ to convert them to fluxes $(\mathrm{kg} /$ $\mathrm{km}^{2} \mathrm{yr}$ ).

\section{A2. NorthGRIP1}

[23] Since the NorthGRIP1 record we used only contains the sulfate content (in $\mu \mathrm{eq} / \mathrm{kg}$ ) corresponding to annual depth intervals and the $55 \mathrm{~cm}$ average ice or snow density for the first $100 \mathrm{~m}$ of ice core, we used the following procedure to calculate the sulfate fluxes.

[24] 1. Linearly interpolate the $55 \mathrm{~cm}$ averaged densities for the first $100 \mathrm{~m}$ of ice core to the depth intervals that corresponding to the annual depositions.

[25] 2. Assume the ice density as $0.85 \mathrm{~kg} / \mathrm{L}$ for the data after the first $100 \mathrm{~m}$.

[26] 3. Multiply the sulfate content (in $\mu \mathrm{eq} / \mathrm{kg}$ ) with the factor $\left[L=48\left(\mathrm{~g} / \mathrm{eq} \mathrm{SO}{ }^{2-}\right) \times\right.$ annual deposition (in $\left.\mathrm{m}\right) \times$ ice density for each annual depth interval ( in $\mathrm{kg} / \mathrm{L}$ )] to convert them to fluxes $\left(\mathrm{kg} / \mathrm{km}^{2} \mathrm{yr}\right)$.

\section{A3. Cores With Sulfate Contents in $\mu \mathrm{g} / \mathrm{L}, \mathrm{ng} / \mathrm{g}$, or $\mathbf{p p b}$}

[27] 1. Assume the density of the sample solution is the same as that of water, i.e., $1 \mu \mathrm{g} / \mathrm{L} \approx 1 \mu \mathrm{g} / \mathrm{kg}=1 \mathrm{ng} / \mathrm{g}=$ $1 \mathrm{ppb}$.

[28] 2. Use $1 \mathrm{~kg} / \mathrm{L}$ as the density if the accumulation is in water equivalent, and $0.85 \mathrm{~kg} / \mathrm{L}$ as the density if the accumulation is in ice equivalent.

[29] 3. Multiply the sulfate content with the factor $[L=$ annual accumulation ( $\mathrm{m} / \mathrm{yr}$ in either water or ice equivalents) $\times$ water or ice density (in $\mathrm{kg} / \mathrm{L}$ )] or just with the annual accumulation if it is in $\left(\mathrm{g} \mathrm{cm}^{-2} \mathrm{yr}^{-1}\right)$ or $\left(\mathrm{kg} / \mathrm{km}^{2} \mathrm{yr}\right)$ to convert them to fluxes (in $\mathrm{kg} / \mathrm{km}^{2} \mathrm{yr}$ ).

[30] Acknowledgments. We thank all the scientists who have supplied us with ice core records both for the difficult work of obtaining and analyzing the cores and for allowing us to use them. We thank Philippe Naveau for valuable discussions on signal extraction methods. This work is supported by NOAA grant NA03-OAR-4310155 and the Chaire du Développement Durable de l'École Polytechnique, Paris, France.

\section{References}

Bigler, M., D. Wagenbach, H. Fischer, J. Kipfstuhl, H. Millar, S. Sommer, and B. Stauffer (2002), Sulphate record from a northeast Greenland ice core over the last 1200 years based on continuous flow analysis, Ann. Glaciol., 35, 250-256.
Briffa, K. R., P. D. Jones, F. H. Schweingruber, and T. J. Osborn (1998), Influence of volcanic eruptions on Northern Hemisphere summer temperature over the past 600 years, Nature, 393, 450-455.

Budner, D., and J. H. Cole-Dai (2003), The number and magnitude of large explosive volcanic eruptions between 904 and 1865 A. D.: Quantitative evidence from a new south pole ice core, in Volcanism and the Earth's Atmosphere, edited by A. Robock and C. Oppenheimer, pp. 165-176, AGU, Washington, D. C.

Castellano, E., S. Becagli, M. Hansson, M. Hutterli, J. R. Petit, M. R. Rampino, M. Severi, J. P. Steffensen, R. Traversi, and R. Udisti (2005), Holocene volcanic history as recorded in the sulfate stratigraphy of the European Project for Ice Coring in Antarctica Dome C (EDC96) ice core, J. Geophys. Res., 110, D06114, doi:10.1029/2004JD005259.

Clausen, H., and C. U. Hammer (1988), The Laki and Tambora eruptions as revealed in Greenland ice cores from 11 locations, Ann. Glaciol., 10, 1622.

Cleveland, W. S., and S. J. Devlin (1988), Locally weighted regression: An approach to regression analysis by local fitting, J. Am. Stat. Assoc., 83, $596-610$.

Cole-Dai, J. H., and E. Mosley-Thompson (1999), The Pinatubo eruption in South Pole snow and its potential value to ice core paleovolcanic records, Ann. Glaciol., 29, 99-105.

Cole-Dai, J. H., E. Mosley-Thompson, and L. Thomason (1997), Annually resolved Southern Hemisphere volcanic history from two Antarctic ice cores, J. Geophys. Res., 102, 16,761-16,771.

Cole-Dai, J. H., E. Mosley-Thompson, S. P. Wight, and L. Thomason (2000), A 4100-year record of explosive volcanism from an East Antarctica ice core, J. Geophys. Res., 105, 24,431-24,441.

Delmas, R. J., S. Kirchner, J. M. Palais, and J. R. Petit (1992), 1000 years of explosive volcanism recorded at the South-Pole, Tellus, Ser. B, 44, 335350.

Dixon, D., P. A. Mayewski, S. Kaspari, S. Sneed, and M. Handley (2004), A 200 year sub-annual record of sulfate in West Antarctica, from 16 ice cores, Ann. Glaciol., 39, 1-12.

Fisher, D., and R. Koerner (1994), Signal and noise in four ice core records from the Agassiz Ice Cap, Ellesmere Island, Canada: Details of the last millennium for stable isotopes, melt and solid conductivity, Holocene, 4, $113-120$.

Fisher, D., N. Reeh, and H. Clausen (1985), Stratigraphic noise in time series derived from ice cores, Ann. Glaciol., 7, 76-83.

Fisher, D. A., R. M. Koerner, and N. Reeh (1995), Holocene climatic records from Agassiz Ice Cap, Ellesmere Island, NWT, Canada, Holocene, 5, 19-24.

Free, M., and A. Robock (1999), Global warming in the context of the Little Ice Age, J. Geophys. Res., 104, 19,057-19,070.

Hammer, C. U., H. B. Clausen, and W. Dansgaard (1980), Greenland icesheet evidence of post-glacial volcanism and its climatic impact, Nature, $288,230-235$.

La Marche, V. C., and K. K. Hirschboeck (1984), Frost rings in trees as records of major volcanic eruptions, Nature, 307, 121-126.

Langway, C. C., K. Osada, H. B. Clausen, C. U. Hammer, and H. Shoji (1995), A 10-century comparison of prominent bipolar volcanic events in ice cores, J. Geophys. Res., 100, 16,241-16,247.

Legrand, M., and R. Delmas (1987), A 220 year continuous record of volcanic $\mathrm{H}_{2} \mathrm{SO}_{4}$ in the Antarctic ice sheet, Nature, 327, 671-676.

Legrand, M., and D. Wagenbach (1999), Impact of Cerro Hudson and Pinatubo volcanic eruptions on the Antarctic air and snow chemistry, J. Geophys. Res., 104, 1581-1596.

Mayewski, P. A., W. B. Lyons, M. J. Spencer, M. S. Twickler, C. F. Buck, and S. Whitlow (1990), An ice core record of atmospheric response to anthropogenic sulfate and nitrate, Nature, 346, 554-556.

Mayewski, P. A., L. D. Meeker, M. C. Morrison, M. S. Twickler, S. I. Whitlow, K. K. Ferland, D. A. Meese, M. R. Legrand, and J. P. Steffensen (1993), Greenland ice core signal characteristics: An expanded view of climate change, J. Geophys. Res., 98, 12,839-12,847.

Monzier, M., C. Robin, and J.-P. Eissen (1994), Kuwae ( 1425 A. D.): The forgotten caldera, J. Volcanol. Geotherm. Res., 59, 207-218.

Moore, J. C., H. Narita, and N. Maeno (1991), A continuous 770-year record of volcanic activity from East Antarctica, J. Geophys. Res., 96, $17,353-17,359$.

Mosley-Thompson, E., L. G. Thompson, J. Dai, M. Davis, and P. N. Lin (1993), Climate of the last 500 years: High-resolution ice core records, Quat. Sci. Rev., 12(6), 419-430.

Mosley-Thompson, E., T. A. Mashiotta, and L. G. Thompson (2003), High resolution ice core records of late Holocene volcanism: Current and future contributions from the Greenland PARCA cores, in Volcanism and the Earth's Atmosphere, edited by A. Robock and C. Oppenheimer, pp. 153-164, AGU, Washington, D. C.

Naveau, P., C. Ammann, H.-S. Oh, and W. Guo (2003), An automatic statistical methodology to extract pulse-like forcing factors in climate 
time series: Application to volcanic events, in Volcanism and the Earth's Atmosphere, Geophys. Monogr. Ser., vol. 139, edited by A. Robock and C. Oppenheimer, pp. 177-186, AGU, Washington, D. C.

Palmer, A. S., V. I. Morgan, A. J. Curran, T. D. Van Ommen, and P. A. Mayewski (2002), Antarctic volcanic flux ratios from Law Dome ice cores, Ann. Glaciol., 35, 329-332.

Pang, K. D. (1993), Climatic impact of the mid-fifteenth century Kuwae caldera formation, as reconstructed from historical and proxy data, Eos Trans. $A G U, 74,106$.

Robock, A. (2000), Volcanic eruptions and climate, Rev. Geophys., 38 $191-219$.

Robock, A., and M. P. Free (1995), Ice cores as an index of global volcanism from 1850 to the present, J. Geophys. Res., 100, 11,549-11,567.

Robock, A., and M. Free (1996), The volcanic record in ice cores for the past 2000 years, in Climatic Variations and Forcing Mechanisms of the Last 2000 Years, edited by P. Jones, R. Bradley, and J. Jouzel, pp. $533-$ 546, Springer, New York.

Simarski, L. T. (1996), Constantinople's volcanic twilight, Saudi Aramco World, 47, 8-13

Simkin, T., and L. Siebert (1994), Volcanoes of the World, 349 pp., Geoscience, Tucson, Ariz.

Sommer, S., C. Appenzeller, R. Rothlisberger, M. Hutterli, B. Stauffer, D. Wagenbach, H. Oerter, F. Wilhelms, D. J. Miller, and R. Mulvaney (2000a), Glacio-chemical study spanning the past $2 \mathrm{kyr}$ on three ice cores from Dronning Maud Land, Antarctica: 1. Annually resolved accumulation rates, J. Geophys. Res., 105, 29,411-29,421.

Sommer, S., D. Wagenbach, R. Mulvaney, and H. Fischer (2000b), Glaciochemical study spanning the past $2 \mathrm{kyr}$ on three ice cores from Dronning Maud Land, Antarctica: 2. Seasonally resolved chemical records, J. Geophys. Res., 105, 29,423-29,433.

Stenchikov, G. L., I. Kirchner, A. Robock, H.-F. Graf, J. C. Antuña, R. G. Grainger, A. Lambert, and L. Thomason (1998), Radiative forcing from the 1991 Mount Pinatubo volcanic eruption, J. Geophys. Res., 103, $13,837-13,857$

Stenni, B., M. Proposito, R. Gragnani, O. Flora, J. Jouzel, S. Falourd, and M. Frezzotti (2002), Eight centuries of volcanic signal and climate change at Talos Dome (East Antarctica), J. Geophys. Res., 107(D9), 4076, doi:10.1029/2000JD000317.
Traufetter, F., H. Oerter, H. Fischer, R. Weller, and H. Miller (2004), Spatiotemporal variability in volcanic sulphate deposition over the past $2 \mathrm{kyr}$ in snow pits and firn cores from Amundsenisen, Antarctica, J. Glaciol., 50, $137-146$.

Witter, J. B., and S. Self (2006), The Kuwae (Vanuatu) eruption of AD 1452: Potential magnitude and volatile release, Bull. Volcanol., 68, 1-18, doi:10.1007/s00445-006-0075-4.

Zielinski, G. A. (1995), Stratospheric loading and optical depth estimates of explosive volcanism over the last 2100 years derived from the GreenlandIce-Sheet-Project-2 ice core, J. Geophys. Res., 100, 20,937-20,955.

Zielinski, G. A., P. A. Mayewski, L. D. Meeker, S. Whitlow, M. S. Twickler, M. Morrison, D. A. Meese, A. J. Gow, and R. B. Alley (1994), Record of volcanism since $7000-\mathrm{BC}$ from the GISP2 Greenland ice core and implications for the volcano-climate system, Science, 264, 948-952.

Zielinski, G., J. Dibb, Q. Yang, P. Mayewski, S. Whitlow, and M. S. Twickler (1997), Assessment of the record of the 1982 El Chichón eruption as preserved in Greenland snow, J. Geophys. Res., 102, 30,03130,045

C. Ammann, National Center for Atmospheric Research, 1850 Table Mesa Drive, Boulder, CO 80307-3000, USA

C. Gao and A. Robock, Department of Environmental Sciences, Rutgers-State University of New Jersey, New Brunswick, 14 College Farm Road, New Brunswick, NJ 08901, USA. (cgao@envsci.rutgers.edu; robock@envsci:.rutgers.edu)

P. A. Mayewski, Climate Change Institute, University of Maine, Orono, ME 04469, USA.

S. Self, Department of Earth Sciences, Open University, Milton Keynes MK7 6AA, UK

J. P. Steffenson, H. B. Clausen, M.-L. Siggaard-Andersen, and S. Johnsen, Niels Bohr Institute, University of Copenhagen, Juliane Maries Vej 30, DK-2100 Copenhagen O, Denmark.

J. B. Witter, Hawaii Institute of Geophysics and Planetology, University of Hawaii at Manoa, 1680 East West Road, Post 504, Honolulu, HI 96822 , USA. 